\title{
RESEPSI PENGGEMAR TERHADAP KARAKTER ANIME SHOUNEN MY HERO ACADEMIA, ATTACK ON TITAN DAN HUNTER X HUNTER
}

\author{
Vinny Anugraha Putri ${ }^{1}$ \\ Wisma Nugraha Ch.R. ${ }^{2}$ \\ Suastiwi $^{3}$
}

Diterima Juli. o1, 2021; Disetujui November. o9, 2021

\begin{abstract}
Abstrak: Salah satu komponen penting dalam sebuah film atau serial animasi selain dari cerita adalah karakter. Karakter utama sebagai penggerak plot pada umumnya menjadi titik fokus dan seringkali menjadi karakter favorit dari penggemar. Dalam beberapa serial tidakjarang ditemukan adanya penggemar yang lebih menyukai karakter pendamping. Mengapa hal tersebut dapat terjadi? Belum banyak penelitian mengenai topik resepsi penggemar terhadap karakter dan topik ini sangat menar$i k$ dan penting untuk dipelajari. Masalah resepsi dalam pemahaman karakter dapat dipahami dengan pendekatan naratologi kognitif dengan teori kategorisasi dan personalisasi’ oleh Schneider. Struktur simpati dari Murray Smith juga digunakan untuk secara lebih jauh melihat tingkat keterikatan penggemar dengan karakter favorit mereka. Penelitian ini akan berfokus pada karakter-karakter dari serial anime shounen yang memiliki karakter pendamping yang lebih populer dibandingkan dengan karakter utama. Dari penelitian ini, teridentifikasi enam kategori dalam resepsi penggemar yaitu kepribadian, perkembangan karakter, tujuan, desain/audio-visual, jalinan hubungan antar karakter dan emosi. Penggemar yang secara berkelanjutan mengevaluasi tindakan yang dilakukan oleh karakter dan seberapa dalamnya mereka memahami emosi dan hubungan antar karakter akan berpengaruh pada rasa keterikatan penggemar dengan karakter.
\end{abstract}

Kata Kunci: karakter; resepsi penggemar; keterikatan; anime

${ }^{1}$ Vinny Anugraha Putri adalah mahasiswi sekolah pascasarjana 2019 Universitas Gadjah Mada (UGM) Yogyakarta.

${ }^{2}$ Wisma Nugraha Ch.R. adalah dosen pada Program Studi Magister Pengkajian Seni Pertunjukan dan Seni Rupa Universitas Gadjah Mada (UGM) Yogyakarta.

${ }^{3}$ Suastiwi adalah dosen pada Program Studi Magister Pengkajian Seni Pertunjukan dan Seni Rupa Universitas Gadjah Mada (UGM) Yogyakarta. e-mail : vinnyanugraha@mail.ugm.ac.id

e-mail: krisnugraha@ugm.ac.id

e-mail:triatmodjosuastiwi@gmail.com 


\begin{abstract}
One of the most important components in a film or animated series apart from the story is the character. The main characters who drive the plot generally are the main focus and also naturally became fans' favorite character. In several series it is not uncommon to find fans who prefer second lead characters. Why does it happen? There's not a lot of research regarding the topic of fan receptions to various characters that has been conducted before and it is very interesting and important to be studied. Understanding fans' reception of characters can be understood by means of cognitive narratology approach with 'categorization and personalization' theory by Schneider. Murray Smith's 'structure of sympathy' theory is also used to further look at the engagement level of fans to their favorite characters. This research is focusing on characters from shounen anime series which have second lead characters that are more popular than the main characters. From this study, identified six categories in fans reception which are personality, character development, goals, design / audio-visual, relationships between characters and emotions. Not only understanding relationships between the characters and emotion, fans also closely following and evaluating the actions that the characters did throughout the story, these factors will also have an effect later on the fans'sense and level of engagement to the characters.
\end{abstract}

Keywords: character; fans reception; engagement; anime

\section{Pendahuluan}

Kata anime, seringkali terlintas dalam pikiran mengenai animasi Jepang dengan gayanya yang khas. Di era modern, animasi Jepang lekat dengan istilah anime dari kata bahasa Inggris animation yang di romanisasi menjadi animēshon (Brenner, 2007, 293). Anime terus berkembang dan meraih momentum di tahun 1970-an ketika mencapai pasar TV di seluruh dunia (Tsugata, 2004, 18-21; Pelliteri, 2010). Ledakan popularitas dari anime seperti Dragon Ball, Akira dan Spirited Away membuat anime menjadi salah satu media hiburan yang digemari banyak orang.

Berbicara mengenai anime juga akan dibahas tentang manga. Anime mengacu pada animasi dan manga mengacu pada buku komik. Manga dan anime memiliki keterkaitan yang erat namun memiliki perbedaan dalam bagaimana kedua media tersebut diproduksi. Manga pada umumnya diproduksi dengan warna hitam putih, berbeda dengan komik Barat seperti Mar- vel yang diterbitkan berwarna. Hal ini dikarenakan manga biasanya diterbitkan setiap minggu dan jika dicetak dengan warna akan menguras lebih banyak uang dan memakan banyak waktu. Hubungan penting antara kedua media ini adalah kebanyakan anime berbasis pada cerita yang telah lebih dulu muncul di manga (Paul Wells dalam Napier $(2016,20)$. Manga yang diterbitkan seringkali diadaptasi menjadi sebuah anime. Studio produksi anime biasanya mengambil dari cerita manga yang telah populer. Hal ini juga memudahkan studio karena studio produksi tidak perlu lagi untuk membuat cerita baru.

Industri anime juga membuat kategorisasi anime berdasarkan dari segmentasi pasar. Tren ini dimulai dengan rilisnya majalah manga Shounen Sekai di tahun 1895 hingga 1914 dan Shoujou Sekai di tahun 1906 hingga 1931. (McCarthy, 2014, 16). Shounen, shoujou, seinen dan josei merupakan beberapa contoh 
kategori yang ada. Shounen berarti anak laki-laki dengan target pasar penonton laki-laki. Genre populer dari kategori shounen adalah genre pertarungan, olahraga dan robot. Shoujou berarti anak perempuan dengan target pasar penonton perempuan. (Brenner, 2007, 304). Seinen berarti lelaki muda. Menarget pada pasar pria muda dewasa. (Brenner, 2007, 303). Josei memiliki arti wanita. Josei menarget pada pasar wanita 18 tahun ke atas atau wanita dewasa. (Brenner, 2007, 298).

Versi anime dari suatu manga mempunyai keuntungan yang tidak ditawarkan oleh manga yaitu animasi. Ketika membaca manga, pembaca harus menggunakan imajinasi mereka untuk merasakan suasana dari adegan yang di gambar. Adegan yang awalnya statis menjadi bergerak dan dibantu dengan audio dan musik latar yang dapat menciptakan intensitas dari sebuah adegan yang akan membuat penonton untuk terjun ke dunia fiksi lebih dalam. Anime telah memberikan pengaruh yang besar pada dunia hiburan dengan karakteristiknya yang cukup berbeda dan layak untuk dipelajari. Anime terkenal dengan dinamisnya jalan cerita, tema dan juga karakternya. Penonton yang terbiasa dengan menonton film animasi seperti Disney dapat terkejut ketika menonton anime (Napier, 2016, 8). Bagaimana industri anime Jepang dalam pembuatan cerita, gaya narasi, perumpamaan, humor dan perkembangan sisi emosi dan psikologi jauh lebih kompleks dibandingkan animasi barat (Napier, 2016, 11). Kebanyakan animasi barat seperti Disney lebih ramah untuk publik dan dengan jalan cerita yang lebih mudah untuk ditebak, sedangkan anime seringkali menawarkan per-kembangan cerita yang lebih beragam dan kadang kala lebih gelap dan berat. Hal mendasar mengapa anime dapat menjadi populer adalah fleksibilitas, kreativitas, dan kebebasan di dalamnya yang merupa- kan sebuah perlawanan terhadap ketaatan masyarakat Jepang (Napier, 2016, 26). Ruang animasi mempunyai potensi untuk bebas dari konteks dan digambar seluruhnya dengan imajinasi dari animator. Aspek-aspek khas dari anime seperti bebasnya narasi, gaya gambar, maupun karakter telah memikat perhatian penonton global. Salah satu aspek yang menjadi perbincangan populer di kalangan penonton adalah karakter.

Karakter merupakan salah satu komponen yang sangat penting dalam membangun plot. Plot tidak akan terbangun dengan baik jika tidak ada karakter yang menjalankannya. Tidak akan ada pula terjadinya suatu peristiwa jika tidak ada aksi yang dilakukan oleh karakter. Suatu peristiwa dapat terlihat menarik di mata penonton karena ada karakter yang mengalaminya. Daya ketertarikan penonton akan suatu serial akan sangat terpengaruh dengan karakter-karakter menarik yang ada di dalamnya. Di dalam media yang semakin didorong oleh segi visual, menimbulkan pertanyaan apakah cukup hanya dengan menggunakan desain visual dari karakter itu saja? Apakah karakter dengan desain bagus atau keren sudah cukup untuk dapat membuat penonton merasa terikat dengan karakter tersebut? Apa hal yang diperlukan untuk dapat mem- bangun suatu hubungan yang erat antara penonton dan karakter?

Hubungan antara karakter dan penonton tidak dapat langsung terjalin begitu saja. Sebuah cerita tidak akan berjalan dengan baik jika karakternya dangkal dan membosankan. Maka dari itu, pembuatan karakter haruslah dibuat dengan cermat. Dalam menulis cerita, penulis pasti akan menentukan peran dari para karakternya. Secara garis besar peran dari karakter dapat ditarik menjadi dua yaitu karakter utama dan karakter pendamping. Ketika sebuah serial ditayangkan, kondisi ideal 
yang diharapkan untuk dapat terjadi adalah karakter utama dapat menjadi pusat perhatian dari penonton. Dalam beberapa serial animasi atau film tidak jarang terjadi situasi dimana karakter yang seharusnya menjadi pusat perhatian kalah popularitas dari karakter pendamping. Dapat diambil contoh yang cukup familiar dari serial komik Batman karya Bob Kane terbitan DC Comics yaitu Joker dan Batman. Joker merupakan musuh Batman, seseorang yang memiliki perilaku buruk dan jelas berperan sebagai karakter antagonis, dapat mencuri perhatian penonton. Joker yang misterius dapat menciptakan ikatan dengan penonton karena menimbulkan rasa keingintahuan akan mengapa dan atas latar belakang apa tokoh antagonis itu dapat menjadi jahat. Dari kasus Joker dan Batman, tampak bahwa sebuah karakter walaupun bukan karakter utama dapat menarik perhatian penonton.

Kasus karakter pendamping dapat mencuri perhatian penonton dari karakter utama dan meraih kepopuleran yang setara hingga melebihi ini juga banyak terjadi di berbagai serial anime. Kita dapat membandingkan kedua serial terbitan Weekly Shounen Jump; My Hero Academia karya Kouhei Horikoshi tahun 2014 dengan One Piece karya Eiichiro Oda tahun 1997. Dilansir dari wiki fandom My Hero Academia dan One Piece, dari serial One Piece, karakter Luffy yang merupakan karakter utama selalu sukses untuk menempati peringkat pertama dalam survei ranking kepopuleran resmi yang diadakan Weekly Shonen Jump selama bertahun-tahun. Hal ini menandakan bahwa komikus dari One Piece sukses dalam membuat karakter yang menarik. Sedangkan karakter Deku yang merupakan karakter utama di dalam My Hero Academia mengalami penurunan dalam tiga kali survei, kalah dari karakter bernama Bakugou yang merupakan karakter pendamping. Dalam survei, Bakugou sukses menempati posisi pertama dalam lima kali survei. Idealnya karakter Deku seharusnya menempati posisi yang sama seperti dengan karakter Luffy.

Penonton merespon kedua karakter utama dari kedua serial ini dengan respon yang berbeda. Hal apa yang menyebabkan perbedaan penonton dalam merespon berbagai tipe karakter ini sangat menarik untuk dipelajari. Maka dari hal tersebut, penulis ingin meneliti lebih mendalam mengenai resepsi penonton dan karakter, seperti apa tipe karakter yang menarik di mata penonton, bagaimana penonton merespon karakter, seperti apa perspektif dan cara pemahaman penonton terhadap karakter, dan seberapa terikatnya penonton dengan berbagai tipe karakter yang berbeda-beda.

Kajian resepsi berfokus pada bagaimana penonton membaca atau memahami media seperti film, print atau media online. Pada penelitian ini penulis akan berfokus pada karakter dari serial anime sebagai objek material. Suatu plot tidak akan dapat berkembang tanpa adanya karakter di dalamnya yang melakukan perjalanan di dalam alur yang telah dibuat. Penonton akan secara konstan mengikuti perjalanan dari karakter karena karakter merupakan elemen sentral yang menjalankan dan membentuk alur dari plot. Penonton juga akan selalu berusaha memahami perilaku dan apa yang dilakukan seorang karakter di dalam sebuah serial. Maka dari itu karakter menjadi fokus utama dalam bagaimana cara penonton melihat sebuah karakter. Dalam penelitian ini data yang akan digunakan adalah serial anime yang di dalamnya terdapat karakter pendamping yang lebih populer daripada karakter utama. Peneliti akan melakukan deskripsi dan analisis terhadap enam karakter dari tiga serial anime, adapun beberapa karakter terpilih yang 
akan menjadi fokus peneliti adalah: Deku dan Bakugou dari My Hero Academia, Eren dan Levi dari Attack on Titan, Gon dan Killua dari Hunter X Hunter.

Karakter dari ketiga serial ini termasuk dalam kategori anime shounen. Ketiga serial ini populer di kalangan penggemar namun yang menjadi alasan mengapa karakter dari ketiga serial ini dipilih bukan karena serial tersebut populer tetapi lebih pada adanya karakter pendamping yang lebih populer dibandingkan dengan karakter utama. Ukuran tingkat kepopuleran didasarkan dari hasil survei popularitas karakter resmi yang diadakan oleh penerbit Weekly Shounen Jump secara berkala. Dari hasil survei, karakter Killua menempati posisi pertama dalam tiga kali survei dengan jumlah total 28,651 pemilih dengan perbedaan sebesar 20,106 dari karakter utama Gon dengan jumlah total 8,545 pemilih. Karakter Levi menempati posisi pertama dalam dua kali survei dari tiga kali survei dengan jumlah total 15,688 pemilih dan memiliki perbedaan sebesar 7,655 pemilih dari karakter utama Eren dengan jumlah total 8,033 pemilih. Karakter Bakugou menempati posisi pertama dalam lima kali survei dari enam kali survei dengan jumlah pemilih sebanyak 65,421 dengan perbedaan sebesar 28,896 pemilih dari karakter Deku dengan jumlah 36,525 pemilih. Karakter dari ketiga serial ini terlihat signifikan dalam perbedaan tingkat popularitasnya di kalangan penggemar dan diharapkan mampu mewakilkan bagaimana penonton merespon karakter utama dan karakter pendamping secara garis besar.

\section{Metode Penelitian}

Perancangan metode penelitian perlu dilakukan sebelum memulai penelitian. Penelitian ini menggunakan pendekatan kualitatif. Pendekatan kualitatif berpusat pada pendekatan secara holistik dan umumnya dicirikan dengan pendekatan induktif untuk membangun pengetahuan yang bertujuan untuk menghasilkan makna (Leavy, 9, 2014). Pendekatan ini memungkinkan peneliti untuk membangun pemahaman tentang suatu topik dan bagaimana proses pengungkapan makna. Penelitian dengan model kualitatif akan menghasilkan data kualitatif hasil dari wawancara dengan informan. Penggunaan pendekatan kualitatif diharapkan dapat mengeksplorasi dan menjelaskan fenomena resepsi penggemar terhadap karakter serial anime shounen.

Untuk memahami bagai- mana resepsi penggemar terhadap berbagai karakter anime shounen, data diambil dari berbagai sumber. Sumber data yang digunakan antara lain dari hasil wawancara dengan informan sebagai data primer dan hasil survei popularitas yang diadakan oleh penerbit resmi majalah Weekly Shōnen Jump sebagai data sekunder.

Teknik pengumpulan data yang digunakan di dalam penelitian ini adalah dengan teknik wawancara mendalam antara peneliti dengan informan. Jenis wawancara yang digunakan adalah dengan wawancara mendalam yang terstruktur. Untuk mengumpulkan data, peneliti membuat pedoman wawancara seperti tema yang dibahas atau rincian daftar pertanyaan.

Pertanyaan dalam penelitian kualitatif secara umumnya bersifat induktif atau terbuka dan dibuat dengan bahasa yang tidak mengarahkan. Jenis pertanyaan dengan pertanyaan terbuka akan mendorong informan untuk menjawab pertanyaan dengan bebas tanpa dibatasi dalam rangkaian kemungkinan respon yang telah ditentukan. Pertanyaan yang ditanyakan merupakan pertanyaan umum, 
peneliti tidak mengarahkan jawaban dari informan dan sebelum memulai wawancara telah memiliki landasan pengetahuan dengan teori yang digunakan dalam penelitian ini agar data wawancara dapat terkumpul secara akurat. Daftar pertanyaan mem- pertimbangkan urutan pertanyaan, dimulai dari pertanyaan umum hingga pertanyaan yang lebih spesifik. Pertanyaan yang disusun dalam dibuat menggunakan teori 'Kategorisasi dan Personalisasi' oleh Schneider dan 'Struktur Simpati' oleh Murray Smith. Dengan cara ini peneliti dapat melihat bagaimana resepsi penggemar terhadap karakter, mengidentifikasi tipe karakter seperti apa yang populer dan melihat perbandingan tingkat keterlibatan antara karakter pendamping dan karakter utama dengan penggemar. Total jumlah pertanyaan ada enam pertanyaan dan akan ditanyakan pada informan ketika wawancara berlangsung.

Peserta dari penelitian direkrut sesuai dengan tujuan dan pertanyaan penelitian. Penelitian mengandalkan teknik purposive sampling atau pengambilan sampel yang bertujuan. Prosedur yang digunakan dalam penelitian ini adalah dengan snowball sampling. Snowball sampling merupakan proses di mana setiap peserta mengarahkan pada pemilihan peserta lain (Adler dan Clark, 2011; Patton, 2015). Peneliti dapat bertanya langsung kepada peserta untuk dapat menyarankan siapa yang dapat menjadi informan yang sesuai. Informan dibagi menjadi tiga yaitu informan kunci, utama dan pendukung. Dalam penelitian ini, yang dipilih menjadi informan lebih spesifik kepada penggemar yang secara berkelanjutan mengikuti cerita dari ketiga serial yang diteliti dan bukan penonton kasual. Informan yang dipilih sebagai informan kunci merupakan seorang penggemar yang memiliki kegemaran dalam menonton ketiga serial anime shounen yaitu My Hero Academia, Attack on Titan dan Hunter X Hunter, mengetahui pengetahuan tentang anime shounen yang cukup luas dengan familiarnya akan istilah dalam anime, wanita berumur 24 tahun, berlatar belakang lulusan sastra Jepang dan aktif dalam komunitas penggemar. Informan kunci kemudian bergulir untuk menyarankan informan berikutnya. Total informan berjumlah empat orang informan dengan gender dua orang perempuan dan dua orang laki-laki.

Wawancara dengan informan dilakukan dari bulan Maret hingga Mei 2021. Pada saat wawancara berlangsung, peneliti secara seksama melihat bagaimana proses resepsi penonton terhadap karakter dan seberapa dekatnya mereka dengan karakter serial anime yang mereka ceritakan dan menganalisisnya. Peneliti pertama- tama melihat bagaimana proses kerja pemahaman penggemar akan karakter. Bagaimana penggemar memahami seorang karakter dapat dilihat dengan Bagan 1 berikut:

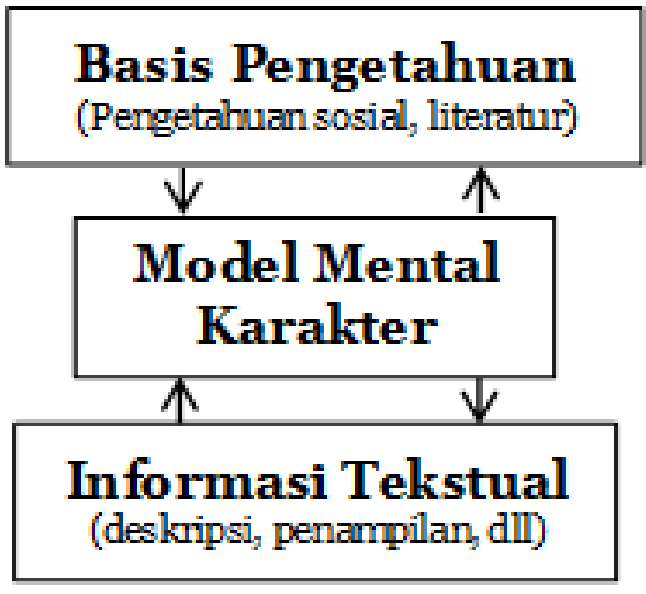

Gambar 1. Bagan Model Mental Karakter

Ketika mengkonstruksi model mental karakter ada dua model utama yang diaktifkan dalam dinamika proses resepsi karakter (Schneider 2001; Gerrig dan Allbritton; 1990). Dua model ini adalah 
'kategorisasi' dan 'personalisasi'. Dari pengetahuan dan informasi yang mereka dapatkan dari menonton, penggemar akan masuk mencoba untuk mencocokan informasi ke dalam 'kategori'. Pembuatan kategori dapat selesai di tahap awal dengan pembuatan kategori pertama, penggemar juga dapat secara terus menerus memperbaharui model mental dan membuat kategori baru setiap kali mereka menerima informasi baru dan penggemar juga dapat masuk ke dalam proses personalisasi jika tidak dapat menemukan kategori yang sesuai untuk karakter (Bagan 2).

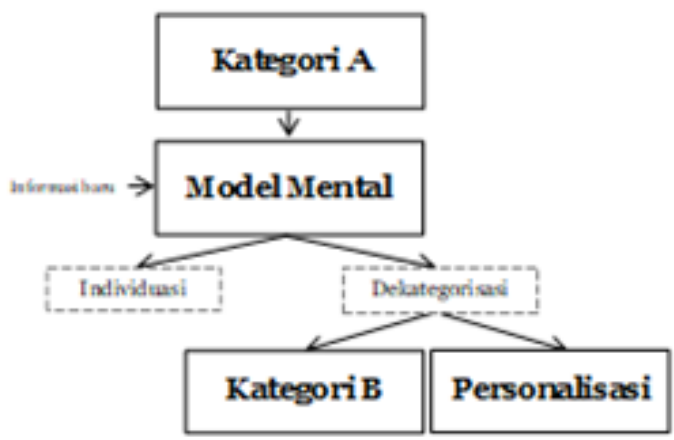

Gambar 2. Bagan Proses Kategorisasi dan Personalisasi

Setelah mengetahui bagaimana alur proses resepsi penggemar terhadap karakter, peneliti kemudian meneliti seberapa dalamnya kelekatan penggemar dengan karakter favorit mereka dengan teori struktur simpati dari Smith. Struktur simpati memiliki tiga tingkat keterlibatan yakni recognition (pengakuan), alignment (keselarasan), dan allegiance (kesetiaan). Recognition adalah konstruksi penonton akan karakter (Smith, 2004, 82). Pada umumnya bergantung pada penampilan luar, ciri-ciri fisik yang terlihat seperti tubuh, wajah dan suara (Smith, 2004, 114, 116). Alignment adalah proses dimana penonton ditempatkan dalam kaitannya dengan karakter dalam hal akses ke tindakan dan apa yang mereka ketahui dan rasakan. (Smith, 2004,
83). Alignment merujuk pada bagaimana penonton mengakses perasaan, pengetahuan dan tindakan yang dilakukan oleh seorang karakter. Allegiance berkaitan dengan evaluasi moral dari karakter oleh penonton (Smith, 2004, 84). Hubungan antara kedua teori yang digunakan dalam penelitian ini dapat dilihat dengan Bagan 3 berikut.

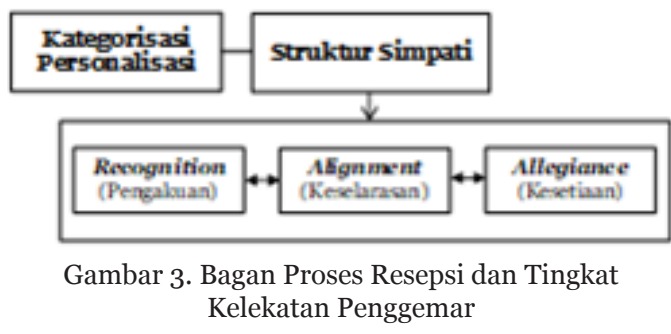

Penggunaan kedua teori 'kategorisasi dan personalisasi' oleh Schneider dan 'struktur simpati' oleh Smith ini saling berkaitan untuk penelitian yang dilakukan. Sebelum meneliti bagaimana perbedaan respon penggemar antar karakter, peneliti haruslah mengetahui bagaimana penggemar memahami karakter yang ada dan hal ini dapat dibantu dengan teori 'kategorisasi dan personalisasi'. Teori 'kategorisasi dan personalisasi' ini mampu membantu peneliti untuk memahami alur pemahaman penggemar terhadap karakter. Setelah memahami bagaimana alur pemahaman dapat terbentuk, kita perlu mengetahui bagaimana penggemar terikat dengan suatu karakter tertentu, oleh karena itu digunakanlah teori 'struktur simpati' oleh Smith sebagai jembatan penghubung. Peneliti ingin mengetahui mengapa dapat terjadinya perbedaan respon antara karakter utama dan pendamping dan teori 'struktur simpati' dapat digunakan untuk mengukur tingkat keterikatan penggemar antara satu karakter dengan karakter yang lain. Kedua teori ini merupakan pijakan yang penting bagi peneliti untuk memahami resepsi penggemar terhadap karakter an- 
ime shounen.

Setelah wawancara dengan informan selesai dan data wawancara terkumpulkan, dilakukan transkrip wawancara. Metode analisis kualitatif digunakan dalam penelitian ini. Secara umum proses analisis dan interpretasi data dimulai dari: penyiapan dan pengorganisasian data, koding, pengkategorian data dan interpretasi data. Pertama data disiapkan dan diorganisir kemudian dilakukan transkripsi data. Data yang didapatkan dibagi menjadi potongan-potongan data, dari banyaknya data yang didapatkan, data dapat dipilah, dikurangi, diringkas dan data yang dapat membantu menjawab pertanyaan penelitian di- prioritaskan agar mudah untuk diinterpretasikan. Pada proses koding, ditetapkan kata deskriptif pada segmen data untuk menangkap esensi dari segmen data tersebut. Setelah data melalui proses koding, kode yang serupa di satukan dalam satu grup atau dikategorisasi. Kemudian data diinterpretasi untuk mencari tahu apa arti dari data yang diperoleh.

\section{Hasil dan Pembahasan}

Dalam mempelajari mengenai resepsi penggemar terhadap karakter anime shounen, peneliti mengajukan sejumlah pertanyaan yang telah dibuat sebelumnya kepada penggemar dalam sesi wawancara. Para penggemar memberikan respon yang detail dalam bagaimana mereka memahami karakter- karakter anime yang mereka tonton dalam bentuk penjelasan serta dapat menceritakan ulang kembali suatu adegan tertentu yang dilakukan oleh karakter favorit mereka. Data yang didapatkan dari hasil wawancara kemudian dikategorisasikan. Peng- gunaan kategori dapat membantu peneliti untuk mendefinisikan dan membandingkan karakteristik antar kategori. Penggunaan kategori dirasa cocok oleh peneliti karena kita mencari "apa" yang ada di dalam tanggapan penggemar dan dari kategorisasi, peneliti menjadi lebih mudah untuk membedakan kategori yang ada karena karakteristik dari setiap kategori sudah terlihat dan telah disatukan dalam satu tempat. Melalui sesi wawancara ini teridentifikasi enam kategori dalam resepsi penggemar yaitu kepribadian, perkembangan karakter, tujuan, desain /audio-visual, jalinan hubungan antar karakter dan emosi.

Bagaimana cara seorang penggemar meresepsi suatu karakter? Semua jenis informasi yang mereka dapatkan akan masuk dalam model mental karakter yang penggemar bangun. Para penggemar menilai karakter berdasarkan dari informasi tekstual yang mereka dapatkan selama mereka menonton. Beberapa informasi yang mereka dapatkan adalah seperti dari segi desain, dimensi emosi karakter, kepribadian, cara berpikir dan ekspresi yang ditunjukkan oleh karakter, tujuan yang dimiliki karakter juga hubungan antar karakter. Informasi-informasi ini penting dalam proses pemahaman penggemar akan karakter. Informasi akan karakter yang mereka dapatkan akan selalu penggemar kumpulkan dan mereka ingat dalam memori (Bagan 4).

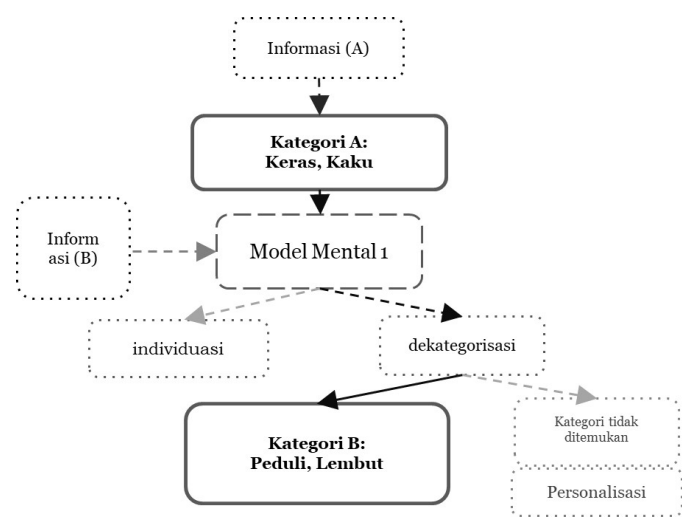

Gambar 4. Bagan Proses Alur Pemahaman Penggemar Terhadap Karakter 
Sebagai contoh dari penggemar yang mengatakan bahwa karakter Levi adalah seseorang yang galak; dari informasi yang pertama penggemar dapat-kan, penggemar terlihat membuat kategori pertama yaitu kategori galak. Penggemar sampai pada pembuatan kategori galak tersebut berdasarkan sisi yang galak, pemarah atau keras yang ditunjukkan oleh karakter Levi. Ketika penggemar melanjutkan proses menonton, Levi menunjukkan sikap peduli terhadap karakter lain. Sikap peduli ini ditangkap oleh penggemar sebagai informasi baru tentang karakter Levi. Model mental karakter dari penggemar kemudian masuk dalam proses individuasi, yaitu proses penyetoran informasi baru. Di sini mereka mendapatkan informasi baru bahwa karakter Levi ternyata memiliki sifat peduli. Penggemar mengatakan bahwa Levi “...ternyata aslinya peduli”, di sini memperlihatkan bahwa penggemar melakukan proses dekategorisasi kategori galak menjadi sebuah kategori baru, yaitu kategori peduli. Penggemar tidak masuk dalam proses personalisasi karena sukses untuk menyimpulkan karakter tersebut ke dalam kategori yang baru. Kategori ini akan selalu terbarui ketika mendapatkan informasi-informasi baru.

Penjelasan yang diberikan oleh penggemar dalam menjawab pertanyaan peneliti, teridentifikasi ada enam kategori besar dalam resepsi penggemar yaitu kepribadian, perkembangan karakter, tujuan, desain /audio-visual, jalinan hubungan antar karakter dan emosi. Tanggapan umum yang diberikan oleh penggemar disortir dan dimasukkan sesuai dengan kategori yang tepat. Urutan dari kategori-kategori ini muncul berdasarkan dari urutan dari pertanyaan yang ditanyakan peneliti kepada penggemar.

Kategori 'kepribadian' terdiri dari tanggapan penggemar yang mengekspresikan tanggapan yang menyinggu- ng segi kepribadian dari karakter. Sisi kepribadian disinggung sebanyak empat kali dengan penggemar yang memberikan keterangan seperti "peduli, cerdas, kuat". Setiap penggemar mengobservasi karakter, penggemar akan mencoba untuk mencari dan menggunakan kata-kata yang tepat seperti "keras" atau "peduli” yang dapat mendeskripsikan karakter tersebut. Penggemar mampu untuk menangkap ciri kepribadian yang ditunjukkan karakter seperti tanggapan "...tipe karakter guru khas guru yang keras”, “... tipe yang galak”. Secara lebih jauh mengapa penonton dapat lebih menyukai karakter favorit mereka juga disebabkan oleh pesona tersembunyi yang dimiliki oleh karakter tersebut. Pesona yang paling signifikan disinggung oleh para penggemar adalah karakter yang misterius.

Beberapa penggemar menyebutkan bahwa mereka menyukai karakter yang tidak mudah untuk terbawa emosi dan tidak mudah untuk ditebak jalan pikirannya. "Isi kepalanya (Levi) tidak bisa dibaca, misterius, Eren di sisi lain isi kepalanya gampang terbaca karena dia emosional, saya lebih menyukai karakter tidak gampang terbawa emosi" . Penggemar juga menyukai pesona yang bertolak belakang atau tidak biasa dari sifat yang ditunjukkan oleh karakter dalam kesehariannya. “...apalagi Levi ternyata gemar bersihbersih, bertolak belakang dari perilaku yang sering ditunjukkan pada saat beraksi (membunuh Titan)". Levi yang terkenal bengis terhadap titan dan ditakuti oleh bawahan dapat dianggap hanya seorang yang kasar dalam kesehariannya dan ketika diketahui memiliki pesona yang tidak lazim yaitu sisi menyukai kebersihan ini membuat daya tarik Levi menjadi semakin lebih kuat.

Kategori 'perkembangan karakter' ini dimana penggemar memahami karakter dari bagaimana karakter berkembang. 
Perkembangan karakter disinggung oleh semua penggemar dalam tanggapan mereka. Salah satu tanggapan yang diberikan yaitu "Saya menilai karakter dari kesimpulan tentang mereka yang saya tangkap setelah nonton atau baca dari awal sampai akhir dan juga dari hal yang paling terlihat menonjol dari mereka". Penggemar menilai karakter dari bagaimana mereka berevolusi, apa saja perubahan yang terjadi dan kesimpulan informasi tentang karakter yang mereka tangkap setelah menonton dari awal hingga akhir. Bagaimana karakter berkembang menjadi hal yang pasti dalam usaha untuk memahami karakter.

Kategori 'tujuan' merupakan kategori dimana penggemar memahami karakter favorit mereka berdasarkan tujuan yang karakter miliki. Karakter yang mempunyai tujuan dan bagaimana usaha yang dilakukan oleh para karakter untuk merealisasikan tujuan mereka dianggap lebih menarik di mata penggemar.

Kategori 'desain /audio-visual' dari karakter turut menyumbang dalam rasa ketertarikan para penggemar terhadap karakter. Kategori ini merupakan kategori bagaimana penggemar menilai segi desain dari karakter. Penggemar meng- ungkapkan daya tarik dari karakter favorit mereka adalah penggambaran yang tidak biasa. Sebagai contoh penggambaran Levi yang bertubuh pendek bertolak belakang dari stereotip karakter kuat yang cenderung digambarkan memiliki badan muskular atau tinggi. "Kalau dia (Levi) proporsional pasti akan terlihat membosankan, Levi yang digambarkan memiliki badan kecil terlihat lucu".

Seberapa eratnya tingkat keterikatan penggemar dengan karakter akan banyak dipengaruhi oleh faktor seperti transfer perspektif karakter dengan penggemar, rasa afeksi penggemar terhadap karak- ter: emosi karakter eksplisit atau tersirat, reaksi penggemar tentang mental karakter, ekspresi emosi dan evaluasi karakter.

Kategori 'emosi' cukup luas dan akan saling berkaitan baik ke dimensi hubungan antar karakter hingga sisi desain. Kategori ini termasuk tanggapan akan mencakup bagaimana penggemar memahami dimensi emosi baik yang diekspresikan tersirat maupun tersurat serta dimana penggemar menempatkan sudut pandangnya dalam melihat karakter. Penggemar dapat menangkap emosi yang digambarkan, sebagai contoh dari hanya adegan yang menunjukkan sorot mata atau aksi pertarungan.

Dalam teori strukturalis, karakter dan setting atau latar yang berada di dalam bagian dari eksistensi dari cerita akan memiliki relasi yang sangat erat, sehingga sangat diperlukan juga untuk memperhatikan latar yang ada di belakang karakter. Latar yang dimaksud bisa seperti latar dari musik dan juga grafis atau desain. Dari sisi desain, penggemar memberikan tanggapan yang berbeda dalam bagaimana mereka dapat menangkap atau merasakan emosi. Salah satu penggemar dengan gender perempuan memberikan tanggapan bahwa manga Attack on Titan pada awalnya terasa kurang bagus karena gambarnya yang kasar tidak seperti gambar manga shoujou (manga yang ditargetkan untuk pasar wanita) dan hal tersebut mempengaruhi dirinya untuk tetap melanjutkan untuk mengikuti serial tersebut atau tidak. Sedangkan penggemar yang lain dengan gender laki-laki, mengatakan emosi yang digambarkan di manga dapat lebih terasa dibandingkan dengan versi anime. Hal ini menunjukkan selera gaya gambar dan juga tingkat kedetailan gambar akan berpengaruh terhadap penerimaan emosi penggemar. Dari hal ini juga menunjukkan adanya perbedaan resepsi antara bagaimana 
penggemar perempuan dan laki-laki dalam merasakan emosi. Bagi penggemar perempuan kedetailan gambar berpengaruh karena telah terbiasa dengan gambar manga shoujou yang cenderung lebih halus, penggunaan screen tone yang lebih detail dalam efek dan gambar latar, sedangkan dari penggemar laki-laki detail-detail seperti hal itu bukan menjadi perhatian paling utama mereka.

Pendekatan yang dilakukan untuk menunjukkan bagaimana karakter terasa lebih hidup pada dua media ini juga cukup berbeda. Pada versi manga karakter dapat terasa hidup bagi penggemar karena adanya faktor guratan garis yang tidak bisa diperlihatkan jika menonton versi anime. Kesan hidup, penyampaian emosi dapat dibangkitkan dari gerutan garis, tebal tipis garis, screen tone dan shading. Gerutan garis tidak dapat secara utuh diperlihatkan dalam anime. Hal ini dikarenakan anime pada umumnya digambar dengan teknik cel shading.

Pengunaan teknik cel shading ini merupakan teknik yang populer dalam industri animasi. Penggunaan teknik cel shading ini dapat mempermudah animator untuk menganimasikan gambar karena animasi membutuhkan konsistensi. Konsistensi lebih mudah untuk dicapai dengan teknik ini, karena pergerakan karakter hingga bayangan karakter lebih mudah untuk dilacak dan dilihat perubahan tiap frame-nya. Jika setiap garis atau gambar tidak saling sambung menyambung tiap detiknya maka animasi akan terlihat kaku. Selain dari sisi animasi, kita dapat merasakan karakter dan suasananya lebih hidup karena telah diberikan suara, di dalam manga suara digambarkan dengan onomatopoeia atau bunyi yang mengekspresikan suara. Jika membaca manga, penggemar dituntut untuk dapat membayangkan suara-suara itu beserta dengan gerakannya. Di dalam anime, otak tidak perlu bekerja ekstra untuk mem bayangkan bagaimana adegan tarung yang terjadi dan bagaimana suaranya karena sudah digerakkan dan diberi musik latar dan juga dubbing oleh para pengisi suara.

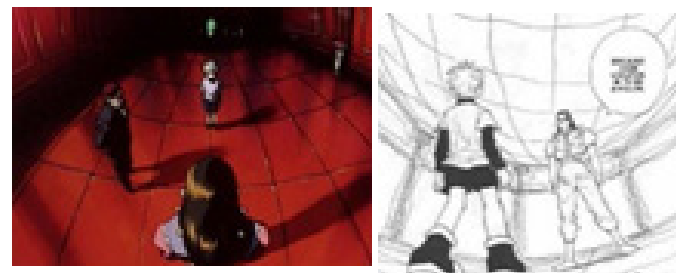

Gambar 5. 1. Perbandingan Anime dan Manga Hunter X Hunter

Cara manga untuk menciptakan suasana dan melecut emosi akan sangat dipengaruhi oleh penempatan panel dan pengambilan sudut pandang. Dalam versi anime dari adegan Killua bertemu kakaknya bernama Illumi dalam episode 21, terlihat lebih mencekam dikarenakan pengambilan sudut pandang dari atas atau komposisi mata elang, sehingga Killua terasa lebih kecil dan lemah di hadapan kakaknya. Sedangkan versi manga digambarkan dengan komposisi mata katak atau dari bawah, dari posisi ini Killua tidak terlalu terlihat dalam posisi yang lemah dan lebih menunjukkan diri Illumi. Pengambilan sudut pandang yang seperti ini dapat membuat penggemar turut merasakan suasana mencekam yang berbeda.

Kategori 'jalinan hubungan antar karakter' berkaitan dengan apa yang diistilahkan oleh Murray Smith dengan tingkat alignment atau keselarasan. Dimensi perasaan atau tindakan yang dilakukan oleh karakter semua disimpan oleh karakter di dalam ingatan. Semakin banyak informasi yang didapat tingkat kedalaman akses akan karakter akan semakin dalam dan membuat rasa keterikatan penggemar dengan karakter menjadi lebih erat.

Seberapa terikatnya penggemar den- 
gan karakter akan dapat dilihat dari cara penonton mengevaluasi atau terhubung dengan sikap dan nilai yang ada di dalam karakter, hal ini termasuk ke dalam ranah allegiance atau kesetiaan. Salah satu penggemar mengevaluasi tindakan Eren yang melakukan genosida, walaupun tindakan itu kontroversial, penggemar tetap menyetujui hal itu agar sisi musuh juga merasakan yang sama. Penggemar menyukai Eren yang menginginkan kebebasan total karena penggemar juga tidak suka untuk dikekang. Dari bagaimana penggemar mengevaluasi tindakan yang dilakukan Eren dapat diambil kesimpulan, jika karakter memiliki sifat yang disukai atau melakukan tindakan yang mereka juga dapat bersimpati di dalamnya penggemar akan jadi lebih mudah untuk bersekutu dengan karakter.

Mengapa dapat terjadinya perbedaan respon antara karakter utama dan pendamping? Untuk mengetahui apa yang menjadi aspek penentu perbedaan respon karakter kita dapat melakukan komparasi antar karakter. Faktor utama yang menyebabkan penggemar tidak begitu tertarik dengan tokoh utama Deku, Gon dan Eren adalah karena bagi penggemar ketiga karakter ini dianggap terlalu emosional. Tokoh utama dari ketiga serial ini memang cukup berbeda dari tipikal karakter utama dari Shounen Jump (Beberapa karakter populer terbitan Shounen Jump adalah seperti Luffy dari One Piece, Naruto Uzumaki dari Naruto, Goku dari Dragon Ball.). Penggemar sudah terbiasa dengan karakter utama dengan sosok yang percaya diri atau dapat dikatakan 'terang', contohnya Luffy dan Naruto. Sehingga ketika dihadapkan dengan sosok yang tidak biasa, seperti contohnya Deku, sosok yang pemalu, gugup dan gampang sekali menangis; perhatian mereka dapat lari ke sosok yang lebih matang atau kuat secara mental, yang dimana hal ini biasa terdapat dalam karakter pendampingnya.

Apa saja tipe karakter yang ada di dalam anime shounen? Beberapa karakter yang teridentifikasi dapat dikategorikan menjadi dua kategori besar yaitu tipe karakter 'hangat' dan 'dingin'. Dari semua hasil wawancara dengan penggemar, terlihat bahwa karakter yang memiliki aura misterius atau cenderung terlihat dingin dan lebih matang dalam mengambil keputusan menjadi tipe karakter yang banyak digemari oleh penggemar. Salah satu penggemar memberikan tanggapan jika karakter yang Ia sukai juga cenderung memiliki sifat yang sama dengan yang ada di dalam serial ini. Penggemar mencontohkannya dengan Itachi dari serial Naruto; "Itachi meskipun tujuan pembantaiannya beda sama Eren, tapi secara garis besar mereka melakukan hal yang sama." Hal ini menandakan pengetahuan literatur penggemar atau pertemuan penggemar dengan karakter fiksi yang serupa dari serial lain juga dapat mempengaruhi impresi dasar penggemar akan suatu karakter. Dari impresi awal seperti kemiripan antar karakter akan berpengaruh nantinya terhadap keterikatan penggemar dengan karakter yang mereka ikuti karena sudah adanya kecenderungan penggemar untuk menyukai suatu karakter dengan tipe tertentu.

Selain dari kecenderungan pada satu tipe tertentu, adanya penggemar dapat cenderung menyukai karakter pendamping daripada karakter utama bisa ditelisik dari bagaimana penentuan gaya storytelling. Bagaimana cerita diceritakan akan memainkan peran penting dalam seberapa berpengaruhnya apa dari inti yang mereka ambil akan karakter oleh penggemar. Jika kita melihat dari awal bagaimana gaya storytelling yaitu digerakkan oleh karakter atau character-driven dan plot-driven atau digerakkan oleh plot. Gaya penulisan plot-driven akan 
mengutamakan kejadian atau peristiwa. Pencipta membangun peristiwa-peristiwa yang menarik yang bisa saja dapat terjadi secara bersamaan. Salah satu contoh dari plot-driven adalah The Lord of the Rings oleh J.R.R. Tolkien. Frodo walaupun merupakan karakter utama tetapi jika Frodo tidak ada atau digantikan dengan karakter lain, cerita masih dapat terus berlanjut. Peristiwa-peristiwa besar yang sebelumnya sudah terjadi akan tetap berlanjut dan dia hanya secara tidak sengaja ikut hanyut pada peristiwa besar itu. Pencipta merajut plot secara cermat untuk menciptakan cerita yang menyeluruh sehingga per- kembangan karakter bukan menjadi fokus utama atau fokus sekunder daripada perkembangan plot. Ketiga serial yang diteliti ini termasuk pada gaya character -driven yaitu digerakkan oleh karakter. Perkembangan karakter, apa yang karakter pikirkan dan aksi yang dilakukan oleh karakter merupakan beberapa fokus dari gaya character-driven. Apa yang dilakukan oleh karakter akan menciptakan efek sebab-akibat pada peristiwa yang akan terjadi kedepannya. Peristiwa yang dialami oleh karakter memberikan banyak informasi yang digunakan untuk membangun karakter dan mendalami karakter utama. Dalam character-driven pada umumnya akan lebih berfokus pada alur dari karakter utama dan bukan karakter pendamping. Karena fokus alur berada di karakter utama, layer informasi dari karakter pendamping tentu saja tidak akan sebanyak karakter utama. Rasa keingintahuan kepada karakter pendamping dapat saja timbul karena informasi yang lebih sedikit ini. Dari rasa keingintahuan ini dapat menjadi faktor penyumbang dalam kesukaan mereka dengan karakter pendamping favorit mereka.

\section{Kesimpulan}

Penelitian akan bagaimana resepsi penggemar terhadap karakter anime shounen yang dilakukan, teridentifikasi enam kategori informasi dalam resepsi penggemar yaitu kepribadian, perkembangan karakter, tujuan, desain/ audio-visual, jalinan hubungan antar karakter dan emosi. Dari hasil wawancara dengan penggemar, enam kategori informasi ini merupakan informasi yang paling umum menjadi sumber penggemar untuk membangun model mental karakter. Proses konstruksi model mental karakter ini akan dapat dipahami dengan teori 'kategorisasi dan personalisasi' oleh Ralf Schneider. Penggemar secara aktif membuat kategori atau personalisasi terhadap karakter. Model mental karakter yang penggemar buat berdasarkan informasi-informasi yang mereka dapatkan bisa membantu mereka membuat kesimpulan terhadap karakter tersebut.

Mengapa dapat terjadi situasi bahwa karakter pendamping lebih terkenal dibandingkan dengan karakter utama dapat dipahami dengan melihat dan membandingkan tingkat ke- terikatan penggemar dengan karakter. Seberapa terikatnya penggemar dengan karakter dapat dipetakan dengan baik dengan bantuan teori 'struktur simpati' oleh Murray Smith. Berdasarkan hasil wawancara dengan informan, faktor emosi dan jalinan hubungan antar karakter memainkan peranan penting. Rasa afeksi penggemar terhadap karakter dapat naik dan turun dengan seberapa pahamnya mereka terhadap emosi karakter yang ditunjukkan, tindakan atau aksi yang dilakukan dan hubungan antar karakter. Penggemar secara berkelanjutan mengevaluasi tindakan yang dilakukan oleh karakter. Penggemar juga dapat membuat kesimpulan dan mengkategorikan karakter -karakter yang ada menjadi beberapa tipe. Tipe 
umum yang dapat dilihat adalah 'hangat' dan 'dingin'. Aspek penentu mengapa dapat terjadi perbedaan respon antara karakter utama dengan pendamping terukur melalui seberapa terikatnya mereka dengan karakter tersebut. Seberapa terikat penggemar dipengaruhi oleh hal seperti pahamnya mereka dengan emosi yang karakter tunjukkan, keberpihakan penggemar dengan tindakan yang dilakukan karakter hingga kecenderungan penggemar untuk menyukai suatu karakter dengan tipe kepribadian tertentu.

\section{Referensi}

Brenner,R. (2007). Understanding Manga and Anime. https://doi.org/10.5860/ rusq.47n3.301

Canet, F., \& Pérez, H. J. (2016). Character engagement as central to the filmmaker-subject relationship: En construcción (José Luis Guerin, 2001) as a case study. Studies in Documentary Film, 10(3), 215-232. https://doi.org/10.10 8o/17503280.2016.1216298

David, W. (2013). The Cognitive Theory of Character Reception : An Updated Proposal. 24(2), 117-134.

Eder, J. (2010). Understanding Characters. Projections, 4(1), 16-40. https:// doi.org/10.3167/proj.2010.040103.

Evans, E. J. (2008). Character, audience agency and transmedia drama. Media, Culture and Society, 3o(2), 197-213. https://doi. org/10.1177/0163443707086861

Fresno, N. (n.d.). Carving Characters In The Mind . A Theoretical Approach To The Reception Of Characters In Audio Described Films. 59-92.

Frow, J. (1986). Spectacle Binding: On Character. 7(2), 227-250.
Hernández-pérez, M. (2019). Japanese Media Cultures in Japan and Abroad: Transnational Consumption of Manga, Anime, and Media-Mixes. In Japanese Media Cultures in Japan and Abroad: Transnational Consumption of Manga, Anime, and Media-Mixes.

Lauer, G. (2010). Characters in Fictional Worlds: Understanding Imaginary Beings in Literature, Film, and Other Media. Hubert \& Co. GmbH.

Leavy, P. (2017). Research Design: Quantitative, Qualitative, Mixed Methods, Arts-Based, and Community-Based Participatory Research Approaches. The Guilford Press.

McCarthy, H. (2014). A Brief History of Manga. Ilex Press.

Napier, S. J. (2016). Anime from Akira to Howl's moving castle: Experiencing contemporary Japanese animation. St. Martin's Griffin.

Oatley, K., \& Johnson-Laird, P. N. (1987). Towards a Cognitive Theory of Emotions. Cognition and Emotion, 1(1), 29-50. https://doi. org/10.1080/02699938708408362

Polvinen, M., \& Sklar, H. (2019). Mimetic and synthetic views of characters: How readers process "people" in fiction. Cogent Arts and Humanities, 6(1), 1-16. https://doi.org/10.1080/2 3311983.2019.1687257

Schneider, R. (2001). Toward a Cognitive Theory of Literary Character: The Dynamics of Mental-Model Construction. Style, 35(4), 607.

Smith, M. (n.d.). Fiction, Emotion, and the Cinema.

Smith, M. (1994). Altered States: Character and Emotional Response in the 
Resepsi Penggemar Terhadap Karak-

Hunter

Cinema. Cinema Journal, 33(4), 34.

https://doi.org/10.2307/1225898 